\title{
Methodology for UK recruitment into a large-scale international clinical trial
}

\author{
Elizabeth Wincott*, Rejive Dayanandan, Richard Haynes, Michael Lay, Martin Landray, Jane Armitage \\ From 3rd International Clinical Trials Methodology Conference \\ Glasgow, UK. 16-17 November 2015
}

\section{Background}

Recruitment into long-term trials requires identification and screening of potential subjects and strategies to maximize post-randomization compliance. We describe a successful strategy used for UK recruitment into a large international trial assessing the effect of extended release niacin/laropiprant (ERN/LRPT) on cardiovascular outcomes.

\section{Methods}

Ethics and Section 251 of the Health and Social Care Act approval allowed potentially eligible patients to be identified (without consent) from local site's hospital records and invited by a central coordinating office to a local screening appointment.

Following a screening visit and initial run-in phase to standardise background LDL-cholesterol management, those remaining eligible entered an active ERN/LRPT run-in to assess their tolerance of the drug and likely long-term compliance. Participants, if still eligible, were then randomized to ERN/LRPT or placebo.

\section{Results}

Electronic records from 89 hospitals allowed 228,391 potential participants to be invited of whom 24,396 (11\%) attended a Screening visit. Of the 14,237 entering the active ERN/LRPT run-in, 6202 (44\%) withdrew before randomization; the majority (82\%) due to adverse effects from ERN/LRPT. Without this active run-in, randomization of the 8035 participants would have been completed in about half the time but adherence to study treatment and completeness of follow-up after randomization would have been substantially worse than the $77 \%$ and $>99 \%$ achieved respectively, adversely affecting power.

\footnotetext{
University of Oxford, Oxford, UK
}

@ 2015 Wincott et al. This is an Open Access article distributed under the terms of the Creative Commons Attribution License (http:// creativecommons.org/licenses/by/4.0), which permits unrestricted use, distribution, and reproduction in any medium, provided the original work is properly cited. The Creative Commons Public Domain Dedication waiver (http://creativecommons.org/publicdomain/ zero/1.0/) applies to the data made available in this article, unless otherwise stated.
doi:10.1186/1745-6215-16-S2-P122

Cite this article as: Wincott et al:: Methodology for UK recruitment into a large-scale international clinical trial. Trials 2015 16(Suppl 2):P122. and take full advantage of:

- Convenient online submission

- Thorough peer review

- No space constraints or color figure charges

- Immediate publication on acceptance

- Inclusion in PubMed, CAS, Scopus and Google Scholar

- Research which is freely available for redistribution 